\title{
KONTRA PRODUKTIF KETERBUKAAN INFORMASI PUBLIK
}

\author{
Kusma Supriatna \\ Program Studi Ilmu Komunikasi Fakultas Ilmu Sosial dan Ilmu Politik \\ Universitas Serang Raya \\ Jalan Raya Cilegon-Serang Km. 5, Drangong, Serang, Banten \\ Email: kusma humasbtn@yahoo.co.id
}

\begin{abstract}
ABSTRAK
Pemahaman dan Makna Keterbukaan Informasi Publik (Studi Fenomenologi tentang Pemahaman dan Makna Keterbukaan Informasi Publik Terhadap Pejabat Pengelola Informasi dan Dokumentasi (PPID) di Lingkungan Pemerintah Provinsi Banten). Tujuan penelitian adalah untuk mengetahui pemahaman PPID di Lingkungan Pemerintah Provinsi Banten terhadap Keterbukaan Informasi Publik, mengetahui tentang makna pemohon informasi dari PPID di Lingkungan Provinsi Banten dan mengetahui tentang makna keterbukaan informasi publik dari PPID di Lingkungan Pemerintah Provinsi Banten. Metode penelitian yang digunakan dalam penelitian ini adalah metode penelitian kualitatif dengan pendekatan fenomenologi. Teori yang digunakan yaitu Fenomenologi Alfred Schutz, Teori Interaksionisme Simbolik, dan Teori Kontruksi Sosial. Hasil penelitian ini adalah menunjukkan bahwa pemahaman PPID di Lingkungan Pemerintah Provinsi Banten terhadap keterbukaan informasi publik sudah tinggi. PPID sudah mampu melakukan ekstrapolasi, yakni kemampuna melihat apa yang ada dibalik yang tertulis dan kemampuan apa yang akan terjadi akibat berlakunya Undang-undang Nomor 14 Tahun 2008 tentang Keterbukaan Informasi Publik. Makna pemohon informasi bagi PPID di Lingkungan Pemerintah Provinsi Banten adalah sebagai pihak yang berpartisipasi dalam penyelenggaraan pemerintahan, pihak yang menggunakan haknya untuk memperoleh informais publik, pihak yang asal meminta informasi untuk menaikan daya tawar, dan pihak yang menggunakan cara memohon informasi untuk bertemu dengan pejabat. Sedangkan makna keterbukaan informasi publik, dari sisi iedalisme, PPID di Lingkungan Pemerintah Provinsi Banten adalah sebagai keniscayaan, tuntutan reformasi, dan bentuk pengawasan masyarakat. Semenatar itu, dalam pelaksanaannya, PPID memaknai eterbukaan informasi publik sebagai sarana bagi pemohon informasi untuk bertemu dengan para pejabat untuk mencapai "deal deal tertentu", meningkatkan daya tawar pemohon, menambah pekerjaan dan sarana mencari kesalahan orang lain.
\end{abstract}

\section{Latar Belakang}

Reformasi tahun 1998 telah membawa perubahan mendasar dalam kehidupan bermasyarakat, berbangsa dan bernegara. Tuntutan transparansi dan keterbukaan dalam penyelenggaraan pemerintahan merupakan sebuah keniscayaan. Tuntutan itu direspon positif para penyelengara pemerintahan. Maka, lahirlah Undang-undang Republik Indonesia Nomor 40 Tahun 1999 tentang Pers. Undang-undang ini memberikan kebebasan yang luar biasa kepada pers sebagai pilar keempat (fourth estate) dalam demokrasi, setelah kekuatan eksekutif, legislatif dan yudikatif.

Satu dasawarsa setelah melewati masa reformasi, revolusi keterbukaan informasi semakin meluas dengan lahirnya Undang-undang Republik Indonesia Nomor 14 Tahun 2008 tentang Keterbukaan Informasi Publik. Undangundang ini lahir bertujuan untuk mewujudkan tata kelola pemerintahan yang baik dan bertanggungjawab (good governance) melalui penerapan prinsip-prinsip akuntabilitas, transparansi dan supermasi hukum serta 
melibatkan partisipasi masyarakat dalam setiap proses kebijakan publik.

Informasi merupakan salah satu bagian yang sangat penting bagi kehidupan masyarakat di dunia saat ini, terlebih dalam suatu negara demokrasi yang mengenal adanya pengakuan terhadap kebebasan dalam memperoleh informasi bagi rakyatnya. Tertutupnya kebebasan dalam memperoleh informasi dapat berdampak pada banyak hal seperti rendahnya tingkat pengetahuan dan wawasan warga negara yang pada akhirnya juga berdampak pada rendahnya kualitas hidup suatu bangsa. Sementara itu dari segi penyelenggaraan pemerintahan, tidak adanya informasi yang dapat diakses oleh publik dapat berakibat pada lahirnya pemerintahan yang otoriter dan tidak demokratis.

Pemberlakuan UU KIP dalam penyelenggaraan di Indonesia, secara garis besar implikasinya melekat pada dua pihak, yaitu penyelenggara pemerintahan dan masyarakat atau publik. Pada pihak penyelenggara pemerintahan, ada beberapa implikasi penerapan UU KIP, seperti kesiapan pemerintah untuk mengklasifikasikan informasi publik menjadi informasi yang wajib disediakan dan diumumkan secara berkala, informasi yang wajib diumumkan serta merta, informasi yang wajib disediakan, dan informasi yang dikecualikan. Implikasi lain bagi pemerintah pada saat UU KIP diterapkan adalah semua urusan tata kepemerintahan berupa kebijakan-kebijakan publik, baik yang berkenaan dengan pelayanan publik, pengadaan barang dan jasa pemerintah, penyusunan anggaran pemerintah, maupun pembangunan harus diketahui oleh publik, termasuk juga isi keputusan dan alasan pengambilan keputusan kebijakan publik serta informasi tentang kegiatan pelaksanaan kebijakan publik tersebut beserta hasil-hasilnya harus terbuka dan dapat diakses oleh publik. Sehingga ada konsekuensi bahwa aparatur pemerintahan atau badan publik harus bersedia secara terbuka dan jujur memberikan informasi yang dibutuhkan publik.

Sedangkan implikasi penerapan UU KIP terhadap masyarakat atau publik adalah terbukanya akses bagi publik untuk mendapatkan informasi yang berkaitan dengan kepentingan publik, terbukanya akses bagi publik untuk berpartisipasi aktif dalam proses pembuatan kebijakan publik, termasuk didalamnya akses untuk pengambilan keputusan dan mengetahui alasan pengambilan keputusan yang berkaitan dengan kepentingan publik. Kemudian implikasi yang dipandang sangat penting adalah dengan adanya penerapan UU KIP ini daya kritis masyarakat atau publik terhadap kinerja penyelenggaraan pemerintahan terutama pelayanan publik semakin meningkat dan diperkirakan tingkat penilaian atau pengaduan masyarakat atau publik terhadap kualitas layanan publik juga semakin meningkat.

Implikasi lain sejalan dengan meningkatnya daya kritis masyarakat, adalah peningkatan pengetahuan masyarakat mengenai hak-hak mereka dalam pelayanan publik yang disediakan oleh pemerintah. Sehingga apabila suatu saat terjadi ketimpangan atau permasalahan dalam pelayanan publik, maka akan banyak pengaduan masyarakat berkaitan dengan kualitas pelayanan publik tersebut. Meningkatnya pengetahuan masyarakat mengenai proses 
penyelenggaraan pemerintahan, juga merupakan implikasi yang akan dihadapi dalam penerapan UU KIP. Dan, hal tersebut dapat meningkatkan minat dan keinginan masyarakat untuk berperan serta dan berpartisipasi dalam proses penyelenggaraan pemerintahan sesuai dengan kapasitas masing-masing.

\section{Metodelogi Penelitian}

Penelitian ini menggunakan metode fenomenologi, yaitu suatu pendekatan yang mencoba mencari pemahaman bagaimana manusia mengkontruksi makna dan konsepkonsep penting, dalam kerangka intersubyektif karena pemahaman seseorang mengenai dunia dibentuk oleh hubungan kita dengan orang lain. Secara harfiah, fenomenologi adalah studi yang memperlajari fenomena, seperti penampakan, segala yang muncul dalam pengalaman seseorang, cara seseorang mengalami sesuatu, dan makna yang dimiliki seseorang dalam pengalamannya. Namun, dalam hal ini fenomenologi lebih luas dari sekedar fenomena, yakni pengalaman sadar dari sudut pandang orang pertama (yang mengalami secara langsung).

pendekatan yang digunakan dalam penelitian ini adalah pendekatan penelitian kualitatif. Pada penelitian kualitatif, penelitian tidak dimulai dengan menguji teori untuk membuktikan, melainkan sebaliknya. Dalam pendekatan kualitatif, suatu teori dapat muncul dalam proses penelitian.

Model induktif dalam penelitian kualitatif yang digunakan dalam penelitian ini diawali dengan mengembangkan teori atau membandingkan pola dengan teori lain (Creswell,
2003 p.90). Selanjutnya peneliti mencari kerangka teori, kemudian membentuk kategori dalam metode, operasionalisasi konsep, mengajukan pertanyaan dalam wawancara dan mengumpulkan data dan informasi berhubungan dengan teoriteori tersebut. kualitatif dipandang sesuai karena dalam penelitian kualitatif penelitian harus dilakukan secara teliti, mendalam dan menyeluruh untuk memperoleh gambaran mengenai prinsipprinsip umum atau pola-pola yang berlaku umum sehubungan dengan gejala-gejala yang ada dalam lokasi penelitian. Karena topik yang diangkatimplementasi UU KIP- bersifat sangat mendasar sehingga membutuhkan analisa yang mendalam dari berbagai sudut pandang. Kondisi ini menuntut jawaban mengenai hakekat yang ada dalam hubungan di antara gejala-gejala atau konsep. Artinya, alasan penggunaan pendekatan kualitatif karena penelitian ini bertujuan memahami suatu situasi sosial. Termasuk didalamnya adanya peristiwa, peran, interaksi dan kelompok. Metode pendekatan kualitatif merupakan sebuah proses investigasi (Creswell, 2003 p.150)

Selain itu, maksud dari dipilihnya penelitian dengan jenis kualitatif deskriptif yaitu agar hasil yang dicapai dari penelitian ini juga dapat menjadi rekomendasi yang baik, jelas, dan berimbang bagi para pembuat keputusan serta untuk mendukung perencanaan di dalam organisasi. Melalui penelitian ini, penulis juga bermaksud untuk menjelaskan bagaimana makna keterbukaan informasi publik dari PPID di Lingkungan Pemerintah Provinsi Banten.

Sementara itu, penelitian ini juga mengguanakan Paradigma konstruktivis, yaitu 
paradigma di mana kebenaran suatu realitas sosial dilihat sebagai hasil konstruksi sosial, dan kebenaran suatu realitas sosial bersifat relatif (nisbi). Pertama, dilihat dari penjelasan ontologis, realitas yang dikonstruksi itu berlaku sesuai konteks spesifik yang dinilai relevan oleh pelaku sosial. Kedua, paradigma konstruktivis ditinjau dari konteks epistemologis, bahwa pemahaman tentang suatu realitas merupakan produk interaksi antara peneliti dengan objek yang diteliti. Dalam hal ini, paradigma konstruktivis bersifat transaksional atau subjektif. Ketiga, dalam konteks aksiologi, yakni peneliti sebagai passionate participation, fasilitator yang menjembatani keragaman subjektivitas pelaku sosial.

Dalam ilmu-ilmu sosial, paradigma konstruktivis merupakan salah satu dari paradigma yang ada. Dua paradigma lainnya adalah klasik dan kritis. Paradigma konsruktivis berada di dalam perspektif interpretivisme (penafsiran) memiliki tiga jenis, yaitu interaksi simbolik, fenomenologis dan hermeunetik. (Eriyanto 2004:13) menuliskan bahwa dalam konsep kajian komunikasi, teori konstruksi sosial bisa disebut berada di antara teori fakta sosial dan definisi sosial. Dalam teori fakta sosial struktur sosial yang eksislah yang penting. Manusia adalah produk dari masyarakat. Tindakan dan persepsi manusia ditentukan oleh struktur yang ada dalam masyarakat. Institusional, norma, sruktur dan lembaga sosial menetukan individu manusia. Sebaliknya adalah teori definisi sosial, manusialah yang membentuk masyarakat. Manusia digambarkan sebagai identitas yang otonom. Melakukan pemaknaan dan membentuk masyarakat. Manusia yang membentuk realitas, menyusun institusi dan norma yang ada. Teori konstruksi sosial berada di antara keduanya.

Paradigma konstruktivis juga dipengaruhi oleh perspektif interaksi simbolis dan perspektif sruktural fungsional. Perspektif interaksi simbolis ini mengatakan bahwa manusia secara aktif dan kreatif mengembangkan respons terhadap stimulus dalam dunia kognitifnya. Dalam proses sosial, individu manusia dipandang sebagai pencipta realitas sosial yang relatif bebas di dalam dunia sosialnya. Realitas sosial itu memiliki makna manakala realitas sosial tersebut dikontrusikan dan dimaknakan secara subjektif oleh individu lain, sehingga memantapkan realitas itu secara objektif.

Jean Piaget adalah psikolog pertama yang menggunakan filsafat konstruktivisme, sedangkan teori pengetahuannya dikenal dengan teori adaptasi kognitif. Sama halnya dengan setiap organisme harus beradaptasi secara fisik dengan lingkungan untuk dapat bertahan hidup, demikian juga struktur pemikiran manusia. Manusia berhadapan dengan tantangan, pengalaman, gejala baru, dan persoalan yang harus ditanggapinya secaca kognitif (mental). Untuk itu, manusia harus mengembangkan skema pikiran lebih umum atau rinci, atau perlu perubahan, menjawab dan menginterpretasikan pengalaman-pengalaman tersebut.

Dalam penelitian ini, PPID yang notabene adalah aparatur pemerintah menghadapi sebuah kenyataan dihadapkan dengan keterbukaan informasi publik. Aparatur pemerintah diwajibkan memberikan informasi publik yang dihasilkannya kepada masyarakat, baik diminta maupun tidak 
diminta. Selain itu, desakan masyarakat untuk melaksanakan keterbukaan informasi publik sangat kuat.

Sementara di sisi lain, masyarakat sedang mengalami euphoria tentang keterbukaan informasi ini setelah sebelumnya mengalami rezinm ketertutupan sebelum lahirnya Undangundang Republik Indonesia Nomor 14 tahun 2008 tentang Keterbukaan Informasi Publik. Sehingga, aparatur pemerintah dihadapkan untuk melayani permohonan informasi, yang terkadang diajukan dengan tidak realistis dan membabi buta.

Dalam kondisi seperti itu, bagaimana PPID mengkontruksi makna keterbukaan informasi publik berdasarkan pengalaman sadar mereka selama menjadi pelayanan masyarakat dalam bidang informasi publik. Oleh karena itu, penelitian ini mencoba menggambarkan, bagaiman PPID memaknai keterbukaan infromasi publik tersebut.

Data yang digunakan dalam penelitian ini adalah data kualitatif. Data kualitatif sendiri dapat dibagi dalam tiga bentuk yakni interview (wawancara), observations (pengamatan), dan documents (dokumen) (Patton, 2002 : 4). Data yang dipakai dalam penelitian ini adalah data primer dan data sekunder. Data primer adalah data yang diperoleh secara langsung. Data primer di dalam penelitian ini diperoleh melalui wawancara langsung kepada informan. Informan yang dimaksud dalam penelitian ini yaitu pejabat atau pihak-pihak yang memiliki wewenang dan pengaruh terhadap kebijakan yang dibuat oleh Pemerintah Provinsi Banten. Wawancara dilakukan untuk mengetahui bagaimana Makna
Keterbukaan Informasi Publik dari PPID di Lingkungan Pemerintah Provinsi Banten.

Sedangkan definisi dari data sekunder adalah data-data yang diperoleh dari tangan kedua, misalnya data yang diperoleh dari data kepustakaan, Biro Pusat Statistik (BPS), Lembaga Demografi, ataupun lembaga-lembaga sejenis. Data sekunder pada penelitian ini diperoleh melalui studi kepustakaan dalam usaha mendapat informasi pada tahap awal penelitian serta pada saat melakukan analisis. Data kepustakaan yang dikumpulkan terdiri dari buku, jurnal, makalah, artikel surat kabar, dan artikel dari internet terkait UU KIP, kesiapan organisasi terhadap perubahan, manajemen, perubahan organisasi, dan sistem informasi.

\section{Subyek Penelitian}

Subyek penelitian ini adalah Pejabat Pengelola Informasi dan Dokumentasi (PPID) di Lingkungan Pemerintah Provinsi Banten. Berdasarkan Keputusan Gubernur Banten Nomor 499.05/kep673-Huk/2001 tertanggal 1 Agustus 2011 tentang Penetapan Pejabat Pengelola Informasi dan Dokumentasi (PPID) di Lingkungan Pemprov Banten, PPID Pemerintah Provinsi Banten terdiri dari :

1. Tim Pertimbangan

Tim Pertimbangan terdiri dari Sekretaris Daerah, Asisten Tata Praja, Asisten Ekonomi dan Pembangunan, Asisten Administrasi Umum dan Kesejahteraan Rakyat, Staf Ahli Gubernur bidang Hukum dan Hak Asasi Manusia dan Kepala Biro Hukum Sekretariat Daerah.

2. PPID 
PPID dijabat oleh Kepala Biro Hubungan Masyarakat dan Protokol Sekretariat Daerah. Dalam melaksanakan tugas-tugasnya, PPID dibantu oleh :

1) Koordinator Bidang Pengelolaan Informasi, Dokumentasi dan arsip, yang dijabat oleh Kepala Bagian Dokumentasi pada Biro Hubungan Masyarakat dan Protokol Sekretariat Daerah

2) Koordinator Bidang Pelayanan Informasi yang dijabat oleh Kepala Bagian Hubungan dan Penerangan Masyarakaty pada Biro Hubungan Masyarakat dan Protokol Sekretariat Daerah.

3) Koordinator Bidang Pengaduan dan Penyelesaian Sengketa yang dijabat oleh Kepala Bagian Bantuan Hukum pada Biro Hukum Sekretariat Daerah

Koordinator bidang dalam melaksanakan tugasnya dibantu oleh tiga orang pelaksana, yang ditetapkan oleh keputusan Kepala Biro Hubungan Masyarakat dan Protokol selaku PPID.

3. PPID Pembantu

PPID Pembantu tersebar pada setiap Satuan Kerja Perangkat Daerah (SKPD), yang terdiri dari :

1) Sekretaris Badan Perencanaan Pembangunan Daerah Provinisi Banten;

2) Sekretaris Badan Pemberdayaan Perempuan dan Masyarakat Desa Provinsi Banten;

3) Sekretaris Badan Kesatuan Bangsa dan Politik Provinsi Banten;

4) Sekretaris Badan Lingkungan Hidup Daerah Provinsi Banten;
5) Sekretaris Badan Ketahanan Pangan Daerah Provinsi Banten;

6) Sekretaris Badan Perpustakaan dan Arsip Daerah Provinsi Banten;

7) Sekretaris Badan Penelitian dan Pengembangan Daerah Provinsi Banten;

8) Sekretaris Badan Penanggulangan Bencana Daerah Provinsi Banten;

9) Sekretaris Badan Pendidikan dan Pelatihan Provinsi Banten;

10) Sekretaris Badan Koordinasi Penanaman Modal Daerah Provinsi Banten;

11) Sekretaris Badan Kepegawaian Daerah Provinsi Banten;

12) Sekretaris Inspektorat Provinsi Banten;

13) Sekretaris Dinas Bina Marga dan Tata Ruang Provinsi Banten;

14) Sekretaris Dinas Pengelolaan Keuangan dan Aset Daerah Provinsi Banten;

15) Sekretaris Dinas Sosial Provinsi Banten;

16) Sekretaris Dinas Tenaga Kerja dan Transmigrasi Provinsi Banten;

17) Sekretaris Dinas Pertanian dan Peternakan Provinsi Banten;

18) Sekretaris Dinas SDA dan Permukiman Provinsi Banten;

19) Sekretaris Dinas Perindustrian dan Perdagangan Provinsi Banten;

20) Sekretaris Dinas Koperasi dan UMKM Provinsi Banten;

21) Sekretaris Dinas Pendidikan Provinsi Banten;

22) Sekretaris Dinas Pemuda dan Olahraga Provinsi Banten; 
23) Sekretaris Dinas Budaya dan Pariwisata Provinsi Banten;

24) Sekretaris Dinas Pertambangan dan Energi Provinsi Banten;

25) Sekretaris Dinas Kesehatan Provinsi Banten;

26) Sekretaris Dinas Kelautan dan Perikanan Provinsi Banten;

27) Sekretaris Dinas Perhubungan, Komunikasi dan Informatika Provinsi Banten;

28) Sekretaris Dinas Kehutanan dan Perkebunan Provinsi Banten;

29) Kepala Bagian Tata Usaha pada Satuan Polisi Pamong Praja Provinsi Banten;

30) Kepala Bagian Umum pada Sekretariat DPRD Provinsi Banten;

31) Kepala Bagian Kerjasama pada Biro Pemerintahan Sekretariat Daerah Provinsi Banten;

32) Kepala Bagian Dokumentasi dan Informasi Hukum pada Biro Hukum Sekretariat Daerah Provinsi Banten;

33) Kepala Bagian Tata Laksana pada Biro Organisasi Sekretariat Daerah Provinsi Banten;

34) Kepala Bagian Perekonomian pada Biro Perekonomian Sekretariat Daerah Provinsi Banten;

35) Kepala Bagian Analisis Data pada Biro Administrasi Pembangunan Sekretariat Daerah Provinsi Banten;

36) Kepala Bagian Tata Usaha pada Biro Umum dan Perlengkapan Sekretariat Daerah Provinsi Banten;

37) Kepala Bagian Tenaga Kerja dan
Transmigrasi pada Biro Kesejahteraan Rakyat Sekretariat Daerah Provinsi Banten;

38) Kepala Bagian Protokol pada Biro Humas dan Protokol Sekretariat Daerah Provinsi Banten;

39) Kepala Bagian Umum dan Kepegawaian pada Sekretariat Korpri Provinsi Banten;

40) Kepala UPT se Provinsi Banten;

41) Kepala Sub Bagian Tata Usaha pada Kantor Penghubung Provinsi Banten;

42) Kepala Sub Bagian Tata Usaha pada RSUD Malingping Provinsi Banten;

43) Kepala Sub Bagian Umum, Keuangan dan Kepegawaian pada Sekretariat Komisi Penyiaran Indonesia Daerah (KPID) Banten.

Berdasarkan tata pengorganisasian PPID di atas, penulis mengkategorikan subyek penelitian sebagai berikut :

1. Tim Pertimbangan

2. PPID, yang terdiri dari PPID, koorditaor bidang, dan pelaksana

3. PPID Pembantu pada badan-badan di Lingkungan Pemprov Banten dan Sekretariat DPRD Provinsi Banten

4. PPID pembantu pada dinas-dinas di Lingkungan Pemprov Banten

5. PPID pembantu pada biro-biro di Lingkungan Sekretariat Daerah Provinsi Banten dan Sekretariat KORPRI.

6. PPID Pembantu pada kantor/sekretariat komisi/UPTD di Lingkungan Pemprov Banten. 
Para pejabat sebagaimana termaktub dalam keputusan Gubernur tersebut di atas, merupakan calon-calon informan dalam penelitian ini. Sesuai dengan sifat penelitian kualitatif, peneliti tidak membatasi jumlah informan tetapi mengutamakan pemenuhan data yang dibutuhkan penelitian (Bungin, 2003 : 55). Langkah awal peneliti adalah melakukan pendekatan dengan para calon informan. Dalam hal ini, merupakan langkah yang mudah bagi peneliti karena seharihari sering bergaul. Peneliti berada pada lingkungan kerja informan dalam rangka pelaksanaan tugas sebagai pelayan informasi publik maupun dalam rangka keperluan lainnya. Sehingga, merupakan keuntungan bagi penelitian ini, karena diharapkan informan tersebut akan memberikan informasi-informasi apa adanya sesuai dengan pengalaman dn kontruksi makna yang dia miliki dengan lugas dan tanpa rasa prasangka lain-lain. Namun demikian peneliti tetap akan menentukan informan yang betul-betul dapat mengartikulasikan pengalamannya untuk menjawab pertanyaan penelitian, dengan memenuhi kriteria umum sebagai berikut:

1. Informan harus mengalami langsung situasi atau kejadian yang berkaitan dengan topik penelitian. Syarat inilah yang mendukung sifat otentitas penelitian fenomenologi,

2. Informan mampu menggambarkan kembali fenomena yang telah dialaminya, terutama dalam sifat alamiah dan maknanya,

3. Informan bersedia untuk terlihat dalam kegiatan penelitian yang mungkin membutuhkan waktu lama,
4. Informan bersedia diwawancara dan direkam aktivitasnya selama wawancara atau selama penelitian berlangsung,

5. Memberikan persetujuan untuk mempublikasikan hasil penelitian.

(Kuswarno, 2009 : 60)

Salah kendala dalam penelitian dimana peneliti berada dalam lingkungan informan adalah terjadinya bias data hasil penelitian. Untuk itu, peneliti harus menjaga betul sehingga data-data yang diungkapkan informan kepada peneliti adalah benar-benar berdasarkan hasil kontruksi makna dari para informan yang berdasarkan pengalaman sadar mereka yang diungkapkan secara subyektif, yang merupakan hasil interaksi antara informan dengan pemohon informasi. Untuk menjamin tidak terjadi bias peneliti menggunakan kedekatan personal antara peneliti dengan informan, karena biasanya seseorang akan berbicara kepada orang-orang terdekat tentang sesuatu hal secara blak-blakan.

Berdasarkan tahapan-tahapan dan kriteria umum informan di atas, informan bukanlah obyek yang diobservasi semata, tetapi seseorang yang dapat dimintai penjelasannya tentang obyek yang diobservasi. Dalam hal ini, Creswell menyebutnya dengan Gaining Access dan making Rapport mengenai tahapan pengumpulan data yang dilakukan berdasarkan pendekatan siklus pengumpulan data.

\section{Implementasi Keterbukaan Informasi di} Pemprov Banten

Provinsi Banten merupakan Provinsi ke30 di Indonesia. Sebagai daerah otonom, Provinsi Banten terbentuk berdasarkan Undang-undang 
Nomor 23 Tahun 2000, yang disetujui DPR RI pada tanggal 4 Oktober 2000. Sebelum menjadi provinsi, Banten merupakan bagian dari Provinsi Jawa Barat. Sejak berdirinya, Pemerintah Provinsi Banten memiliki komitmen positif untuk mewujudkan pemerintahan yang baik dan bersih (good governace). Hal tersebut terlihat dari misi Provinsi Banten. Setiap periode kepemimpinan di Provinsi Banten selalu menetapkan misi penerapan good governance.

Salah satu pilar penerapan good governance adalah adanya keterbukaan informasi publik. Di Provinsi Banten pelaksanaan keterbukaan informasi publik sudah dilaksanakan jauh sebelum berlakunya Undang-undang Nomor 14 tahun 2008 tentang Keterbukaan Informasi Publik. Secara kelembagaan, pelaksanaan keterbukaan informasi publik dengan dibentuknya lembaga kehumasan di Lingkungan Pemerintah Provinsi Banten. Pada awal pembentukan Pemerintah Provinsi Banten, struktur lembaga kehumasan berbentuk bagian pada Biro Umum dan Perlengkapan Sekretariat Daerah Provinsi Banten, yang kepalanya dijabat pejabat struktural esselon III. Sejak tahun 2002 lembaga kehumasan ini dinaikan statusnya menjadi Biro Humas Sekretariat Daerah Provinsi Banten berdasarkan Peraturan Daerah Nomor 11 tahun 2002 tentang Organisasi dan Tata Kerja Sekretariat Daerah Provinsi Banten, yang kepalanya djabat oleh pejaat struktural esselon II. Demikian juga ketika Pemerintah Provinsi Banten melakukan perombakan terhadap stuktur organisasi pada tahun 2008. Saat itu, lembaga kehumasan di Lingkungan Pemerintah Provinsi Banten bernama Biro Humas dan Protokol berdasarkan Peraturan
Daerah Provinsi Banten Nomor 1 Tahun 2008 tentang Pembentukan Organisasi dan Tata Kerja Sekretariat Daerah Provinsi Banten.

Keberadaan lembaga kehumasan atau public relations (PR) ini ini bertujuan untuk melayani informasi kepada masyarakat oleh Pemerintah Provinsi Banten. Di dunia pemerintahan, PR bertugas menjalankan kegiatan kebijakan publik dan pelayanan publik. Salah satu kegiatan PR pemerintah dalam bidang kebijakan publik adalah memberikan berbagi informasi tentang kebijakan pemerintahan yang mengikat rakyat atau masyarakat (Ardianto, 2011 : 239). Sedangka menurut Mantan Menteri Pendayagunaan Aparatur Negara dan Reformasi Birokrasi Feisal Tamin, fungsi dan peranan humas dalam pemerintahan adalah sebagai berikut : 1). Mengamankan dan terjemahkan kebijakan pemerintah; 2). Memberi pelayanan informasi dan pintu keterbukaan; 3). Menampung dan menyerap informasi; 4). Menjembatani secara aktif pihak instansi dan publik; dan 5). Menciptakan iklim/suasana lingkungan yang baik.

Ketika Undang-undang Nomor 14 Tahun 2008 tentang Keterbukaan Informasi Publik diterbitkan, Pemerintah Provinsi Banten menyambut positif era keterbukaan informasi publik tersebut. Sebelum undang-undang tersebut diberlakukan 29 April 2010, Pemprov Banten melalui Biro Humas dan Protokol sudah ancangancang melaksanakan- nya dengan menerbitkan Keputusan Gubernur Nomor 019.05/Kep.244Huk/2009 Tentang Pembentukan Tim Kehumasan pada Satuan Kerja Perangkat Daerah di Lingkungan Pemerintah Provinsi Banten, dan Keputusan Gubernur 019.05/Kep.292-Huk/2010 
tentang Perubahan Atas Keputusan Gubernur

Banten Nomor 019.05/Kep.244-Huk/2009

Tentang Pembentukan Tim Kehumasan pada

Satuan Kerja Perangkat Daerah di Lingkungan

Pemerintah Provinsi Banten. Tim Kehumasan merupakan para pegawai pada satua kerja perangkat daerah yang siap melayani dan menjembatani kesenjangan informasi antara masyarakat dengan Pemerintah Provinsi Banten. ${ }^{1}$

Secara simultan pada awal tahun 2011, Pemerintah Provinsi Banten melalui Dinas Perhubungan, Komunikasi dan Informatika menfasilitasi pembentukan Komisi Informasi Provinsi Banten. Pada 24 Februari 2011, Gubernur Banten, $\mathrm{Hj}$. Ratu Atut Chosiyah melantik Anggota Komisi Informasi Provinsi Banten masa bhakti 2010-2015 di Pendopo Gubernur Banten. Penetapan anggota Komisi Informasi Provinsi Banten berdasarkan SK Gubernur Banten Nomor 497.05/Kep.69Huk/2011. Menurut Gubernur Komisi Informasi memiliki tugas untuk menerima, memeriksa dan memutuskan permohonan penyelesaian sengketa informasi publik melalui mediasi atau ajudikasi non-litigasi yang diajukan oleh setiap pemohon informasi publik berdasarkan peraturan perundang-undangan yang berlaku serta melaporkan hasil pelaksanaan tugasnya kepada Gubernur dan DPRD Provinsi Banten. Saat itu, Gubernur juga menyampaikan bahwa dalam upaya mewujudkan pemerintahan yang clean governance dan good governance. Komisi Informasi Provinsi Banten menjadi fasilitator untuk penyampaian informasi sebagaimana diamanatkan dalam Undang-undang Nomor 14 tahun 2008 tentang Keterbukaan Informasi Publik.

Pada Agustus 2010, Pemerintah Republik Indonesia menerbitkan Peraturan Pemerintah (PP) Nomor 61 Tahun 2010 tentang Pelaksanaan Undang-undang Republik Indonesia Nomor 14 tahun 2008 tentang Keterbukaan Informasi Publik. Salah satu poin penting PP tersebut adalah memerintahkan kepada badan publik, salah satunya Pemprov Banten, untuk membuat peraturan tentang tata kelola informasi publik dan penujukan Pejabat Pengelola Informasi dan Dokumentasi (PPID) paling lambat 23 Agustus 2011.

Untuk melaksanakan perintah tersebut, tanggal 14 Juli 2011, Pemprov Banten menerbitkan Peraturan Gubernur Banten Nomor 16 tahun 2011 tentang Pedoman Pengelolaan informasi Publik dan Dokumentasi di Lingkungan Pemerintah Provinsi Banten. Peraturan ini mengatur tentang mekanisme pengelolaan dan pelayanan informasi publik dan Dokumentasi di Lingkungan Pemprov Banten.

Peraturan tersebut, kemudian disusul dengan penerbitan Surat Keputusan (SK) Gubernur Banten Nomor 499.05/kep673huk/2001 tertanggal 1 Agustus 2011 tentang Penetapan Pejabat Pengelola Informasi dan Dokumentasi (PPID) di Lingkungan Pemprov Banten. SK tersebut memberikan kewenangan kepada pejabat yang ditunjuk untuk memberikan pelayanan informasi publik kepada masyarakat. ${ }^{2}$

Sampai dengan Oktober 2012, PPID sudah menerima permohonan informasi sebanyak

\footnotetext{
2 Supriatna, Kusma. 2012. Pelayanan Informasi di Pemerintah Provinsi Banten. Menara Banten Edisi IV Tahun 2012. Hal.
} 
83 permohonan. Sebanyak dapat dilayani sesuai dengan permintaan dan pemohon informasi dapat menerima pelayanan itu. Sebanyak 37 kasus mengajukan sengketa informasi kepada Komisi Informasi Provinsi Banten.

Sebanyak 37 kasus diupayakan penyelesainnya melalui mediasi. Dan, sebanyak 37 kasus pula berlanjut hingga ke proses sidang ajudikasi non litigasi, gugatan di Pengadilan Tata Usaha Negara (PTUN) Serang. Dan, satu kasus berlanjut hingga proses kasasi di Mahkamah Agung (MA) Rrepublik Indonesia.

Sambutan positif keterbukaan informasi di Provinsi Banten juga datang dari DPRD Provinsi Banten. Pada 7 Maret 2012, DPRD Provinsi Banten menyerahkan Rancangan Peraturan Daerah (Raperda) mengenai keterbukaan informasi publik di Provinsi Banten. Penyerahan Raperda dari DPRD Provinsi kepada Gubernur Banten tersebut dilaksanakan pada acara Rapat Paripurna Penjelasan DPRD Banten mengenai dua Raperda Prakarsa oleh Pimpinan Badan Legislatif Daerah (Balegda) dan Komisi V DPRD Provinsi Banten.

Dalam Raperda keterbukaan informasi publik, dewan menilai Raperda ini dianggap penting karena keterbukaan informasi harus dilaksanakan secara transparan dan akuntabel. Dengan adanya keterbukaan informasi publik yang transparan dan akuntabel, publik bisa mengontrol kinerja pemerintah. "Dengan adanya kontrol yang langsung dilakukan masyarakat, maka pelayanan terhadap masyarakat pun akan bisa lebih baik lagi," kata Ketua DPRD Banten, Aeng Haerudin, usai rapat paripurna penyerahan
Raperda Prakarsa DPRD tentang Keterbukaan Informasi Publik. ${ }^{3}$

Selain adanya fungsi kontrol langsung dari masyarakat, lanjut Aeng, dengan adanya keterbukaan informasi publik ini bisa dimanfaatkan oleh investor untuk memberikan kepercayaannya kepada Banten dalam menanamkan modalnya. "Raperda keterbukaan informasi publik ini bisa sebagai informasi publik bagi para investor yang ingin menanam modal di Provinsi Banten," katanya.

Raperda tentang Keterbukaan nformasi Publik disayhakan Gubernur Banten Hj. Ratu Atut Chosiyah, SE bersama-sama DPRD Provinsi Banten pada 28 September 2012, bersamaan dengan peringatan Hari Hak Untuk Tahu (Right to Know Day) tahun 2012 dengan nama Peraturan Daerah Provinsi Banten tentang Tata Kelola Keterbukaan Informasi Publik Dalam Penyelenggaraan Pemerintahan Daerah. Dalam sambutannya, Gubernur Banten, Hj. Ratu Atut Chosiyah, SE mengatakan pengesahan Raperda tentang Tata Kelola Keterbukaan Informasi Publik Dalam Penyelenggaraan Pemerintahan Daerah, merupakan komitmen bersama untuk membangun akuntabilitas dan transparansi dalam penyelenggaraan pemerintahan daerah yang baik (good governance), yaitu melalui pelayanan informasi yang disediakan Pemerintah Provinsi Banten, baik melalui media cetak dan/atau elektronik. ${ }^{4}$

\footnotetext{
3 http://bantenposonline.com/2012/03/08/dewan-serahkan-2raperda-inisiatif/. Diakses tanggal 16 November 2012 pukul 22.58 WIB.
} 


\section{Pembahasan}

Semenjak Undang-undang Negara

Republik Indonesia Nomor 14 tahun 2008 tentang Keterbukaan Informasi Publik (UU KIP) disahkan, keterbukaan informasi dalam penyelenggaraan pemerintahan di Provinsi Banten, menjadi sorotan masyarakat. Setahun sebelum undang-undang tersebut dilaksanakan, sejumlah komponen mendesak badan publik, terutama pemerintah daerah untuk segera melaksanakan UU KIP di wilayah Provinsi Banten. Sejumlah LSM, lembaga riset, pers, tokoh masyarakat, dan organisasi mahasiswa gencar melakukan sosialisasi dan mewacanakan UU KIP ini sejak awal tahun 2009. Bahkan, beberapa tokoh masyarakat, berinisiatif membentuk Tim Persiapan Pembentukan Komisi Informasi Publik (TP-KIP) sebagai organisasi taktis yang bersifat ad-hoc yang mewadahi elemen-elemen masyarakat tersebut guna mendorong pemerintah untuk proaktif dalam menyambut pemberlakuan UU KIP ini dengan melakukan percepatan pembentukan Komisi Informasi di Provinsi Banten. TP-KIP ini menjadi satu-satunya organisasi yang aktif mengawal proses pembentukan komisi informasi, sehingga hampir seluruh tahapan seleksi yang diselenggarakan oleh tim seleksi nyaris tidak luput dari pengawasan dan kontribusi dari TP-KIP. ${ }^{5}$ Sebagian besar elemen masyarakat meyakini, pembentukan Komisi Informasi (KI) merupakan titik tolak kehidupan keterbukaan informasi di Banten.

Tanggal 24 Februari 2011, Komisi Informasi Provinsi Banten dilantik Gubernur Banten, Hj. Ratu Atut Chosiyah. Provinsi Banten menempati urutan kelima dalam membentuk Komisi Informasi provinsi. ${ }^{6}$ Terbentuknya Komisi Informasi di Provinsi Banten merupakan harapan masyarakat untuk terciptanya good government di Provinsi Banten. Bertepatan dengan peringatan satu tahun Komisi Informasi Provinsi Banten, Direktur Pusat Telaah dan Informasi Regional (Pattiro) Serang, Patchurrahman mengatakan, KI Banten menanggung harapan besar dari masyarakat karena tujuan akhir dibentuknya KI Banten adalah mewujudkan good government.

Setelah 2 (dua) tahun UU KIP berjalan, tuntutan keterbukaan informasi semakin menguat. Masyarakat yang menggunakan haknya untuk tahu tentang penyelenggaraan pemerintahan makin banyak. Sebagai gambaran, berdasarkan data pada Pejabat Pengelola Informasi dan Dokumentasi (PPID) di Lingkungan Pemerintah Provinsi (Pemprov) Banten, pada tahun 2011, hanya sekitar 15 permohonan informasi yang diajukan masyarakat kepada Pemprov Banten. Permohonan informasi melonjak pada tahun 2012. Sampai dengan Juni 2012, permohonan informasi tersebut mencapi 62 permohonan, yang berasal dari perorangan, Lembaga Swadaya Masyarakat (LSM), organisasi kemasyarakatan, dan lain-lain.

Pada umumnya, permohonan informasi tersebut berhubungan dengan pengelolaan keuangan negara, seperti Dokumen Pelaksanaan Anggaran (DPA), Dokumen Kontrak, Data Pemenang Lelang Pengadaan Barang/Jasa, Data Realisasi Anggaran, dan lain-lain. Selama tahun 2012, hanya satu permintaan informasi yang tidak berhubungan dengan pengelolaan keuangan, yaitu dari organisasi kemasyarakatan Persatuan Pelajar 
Muslim Indonesia (PPMI) Wilayah Banten, yang meminta informasi nama sekolah di seluruh wilayah Provinsi Banten. ${ }^{7}$

Pemerintah Provinsi Banten tidak bisa mengelak atas permohonan informasi tersebut. Undang-undang KIP mengamanatkan, bahwa informasi publik, yang menurut undang-undang didefinisikan sebagai informasi yang dihasilkan, disimpan, dikelola, dikirim, dan/atau diterima oleh suatu badan publik yang berkaitan dengan penyelenggara dan penyelenggaraan negara dan/atau penyelenggara dan penyelenggaraan badan publik lainnya yang sesuai dengan UndangUndang KIP serta informasi lain yang berkaitan dengan kepentingan publik, harus bisa diakses masyarakat.

Maka, untuk meningkatkan pelayanan informasi publik kepada masyarakat, UU KIP mengamanatkan bahwa setiap badan publik, salah satunya Pemerintah Provinsi Banten, harus menunjuk Pejabat Pengelola Informasi dan Dokumentasi (PPID). Menurut UU KIP, Pejabat Pengelola Informasi dan Dokumentasi adalah pejabat yang bertanggung jawab di bidang penyimpanan, pendokumentasian, penyediaan, dan/atau pelayanan informasi di badan publik. PPID ini, menurut Peraturan Pemerintah (PP) Nomor 61 tahun 2010 tentang Pedoman Pelaksanaan Undang-undang Republik Indonesia Nomor 14 tahun 2008 tentang Keterbukaan Informasi Publik, harus sudah terbentuk satu tahun sejak terbitnya PP tersebut, yaitu 23 Agustus 2011.

Dalam melaksanakan perintah undangundang tersebut, tanggal 14 Juli 2011, Pemprov
Banten menerbitkan Peraturan Gubernur Banten Nomor 16 tahun 2011 tentang Pedoman Pengelolaan informasi Publik dan Dokumentasi di Lingkungan Pemerintah Provinsi Banten. Peraturan ini mengatur tentang mekanisme pengelolaan dan pelayanan informasi publik di Lingkungan Pemerintah Provinsi (Pemprov) Banten.

Sedangkan aparatur pelaksana peraturan tersebut, Gubernur telah mengeluarkan Surat Keputusan (SK) Gubernur Banten Nomor 499.05/kep673-Huk/2001 tertanggal 1 Agustus 2011 tentang Penetapan Pejabat Pengelola Informasi dan Dokumentasi (PPID) di Lingkungan Pemprov Banten. SK tersebut memberikan kewenangan kepada pejabat yang ditunjuk untuk memberikan pengelolaan dan pelayanan informasi publik kepada masyarakat sesuai dengan peraturan perundang-undangan tentang KIP.

Sejalan dengan penerbitan berbagai peraturan pelaksanaan dalam implementasi UU KIP, Pemprov Banten juga terus melaksanakan sosialisasi tentang KIP di Lingkungan Pemprov Banten, bahkan kepada pemerintah kabupaten/kota se-Provinsi Banten. Berdasarkan data pada Biro Humas dan Protokol Sekretariat Daerah Provinsi Banten, selama tahun 2010 dan 2011, telah dilaksanakan 8 (delapan) kali sosialisasi tentang undang-undang Keterbukaan Informasi Publik kepada aparatur Pemprov Banten. Bahkan, pada tahun 2011, sosialisasi dikhususkan bagi para calon PPID, yaitu sekretaris dinas/badan pada Satuan Kerja Perangkat Daerah, kepala bagian yang membawahi urusan ketatausahaan pada biro/unit 
kerja, dan kepala sub bagian tata usaha pada kantor/RSUD Malimping/Sekretariat KPID, dan Kepala Bagian Umum pada Sekretariat DPRD Provinis Banten. Hal ini dilaksanakan, dengan tujuan optimalisasi pengelolaan dan pelayanan informasi di Lingkungan Pemprov Banten sesuai UU KIP. ${ }^{8}$

\section{Hasil dan Pembahasan}

\section{Pemahaman PPID terhadap Keterbukaan}

\section{Informasi Publik}

Menurut Kamus Psikologi kata
pernahaman berasal dari kata "insight" yang
mempunyai arti wawasan, pengertian pengetahuan
yang mendalam (Kartono, $7997:$ 170-171). Jadi
arti dari insight adatah suatu pemahaman atau
penilaian yang beralasan mengenai reaksi-reaksi
pengetahuan atau kecerdasan dan kemampuan
yang dimiliki seseorang. Sementara itu, Suryadi
Suryabrata menyatakan insight adalah
didapatkannya pemecahan problem,
didapatkannya persoalan dan mendapat
pencerahan. Pemahaman dapat pula diartikan
menguasai sesuatu dengan pikiran (Suryabrata
l991 : 298). Pemahaman itu bersifat dinamis.
1991 : 298). Pemahaman itu bersifat dinamis. Dengan demikian pemahaman akan bersifat kreatif, ia akan menciptakan imajinasi-imajinasi dengan pikiran yang tenang. Pemahaman merupakan salah satu aspek perilaku manusia sebagai efek dari proses pembelajaran. Benyamin Bloom (1908) membagi perilaku manusia dalam tiga domain, yaitu kognitif, afektif, dan psikomotor. "Dalam perkembangannya teori ini dimodifikasi menjadi pengetahuan, sikap dan

8 Data kegiatan Biro Humas dan Protokol Sekretariat Daerah Provinsi Banten tahun 2010, 2011. praktik (tindakan). Menurut Notoatmodjo (2003), pengetahuan yang tercakup dalam domain kognitif mempunyai 6 (enam) tingkatan, yaitu; 1) Tahu (Know), diartikan sebagai mengingat suatu materi yang telah dipelajari sebehunnya. Orang yang telah tahu harus dapat mendefenisikan materi atau obyek tersebut; 2). Memahami (Comprehension) diartikan sebagai suatu kemampuan untuk menjelaskan secara benar tentang obyek yang diketahui dan dapat menginterpretasikan materi tersebut secara benar; 3). Aplikasi (application), diartikan sebagai untuk menggunakan materi yang telah dipelajari pada suatu situasi atau kondisi real (sebenarnya); 4). Analisis (analisys) adalah suatu komponen untuk menjabarkan suatu materi atau obyek; 5). Sistesis (syntesis) adalah menunjuk pada suatu kemampuan untuk menyusun formulasi baru dari formulasi-formulasi yang ada missal dapat menyusun, merencanakan, meringkas, menyesuaikan dan sebagainya terhadap suatu teori atau rumusan-rumusan yang telah ada; 6). Evaluasi (evaluation) adalah berkaitan dengan kemampuan untuk melakukan justifikasi atau penilaian terhadap suatu materi atau obyek. Penilaian tersebut didasarkan pada suatu kriteria yang ditentukan sendiri atau menggunakan kriteria-kriteria yang telah ada.

Pemahaman memerlukan kemampuan menangkap makna atau arti dari sebuah konsep. Menurut Nana Sudjana (Sudjana 2006 :24), pemahaman dapat dibedakan dalarn tiga kategori, yaitu : a). Tingkat terendah adalah pemahaman terjemah, mulai terjemah dalam arti sebenarnya. Pemahaman terjemah yakni kesanggupan memahami makna yang terkandung didalamnya; 
b). Tingkat kedua adalah pemahaman penafsiran, yakni menghubungkan bagian-bagian dengan yang diketahui berikutnya atau menghubungkan beberapa bagian dari grafik dengan kejadian membedakan yang pokok dan yang bukan pokok, membedakan dua konsep yang berbeda; c). Pemahaman tingkat ketiga atau tertinggi adalah pemahaman ekstrapolasi. Dengan ekstrapolasi diharapkan seseorang mampu melihat dibalik yang tertulis, dapat membuat ramalan tentang konsekuensi atau dapat memperluas persepsi dalam arti wakru, dimensi, kasus ataupun masalahnya. Pemahaman ekstrapolasi yakni kesanggupan melihat dibalik yang tertulis, tersirat dan tersurat meramalkan sesuatu dan memperluas wawasan.

Pemahaman PPID terhadap keterbukaan informasi merupakan salah satu tujuan dalam penelitian ini. Kualitas pelayanan informasi yang diberikan oleh PPID sangat tergantung kepada pemahaman PPID terhadap keterbukaan informasi publik. Peneliti menduga, pemahaman PPID terhadap keterbukaan informasi yang rendah cenderung memiliki kualitas pelayanan informasi yang buruk. Dan sebaliknya kualitas pelayanan informasi yang baik akan diberikan oleh PPID yang memiliki pemahaman yang tinggi terhadap keterbukaan informasi publik.

Menurut kepada tingkatan pemahaman tersebut, semua PPID di Lingkungan Pemerintah Provinsi Banten sudah rurmpu menjelaskan tentang keterbukaan informasi publik dengan bahasa sendiri. Bahkan, pada umumnya ketika peneliti menanyakan pengetahuannya tentang keterbukaan informasi publik, PPID menafsirkan sendiri tentang keterbukaan informasi publik tersebut. Mereka memahami keterbukaan informasi sebagai kewajiban pemerintah atau konsekuensi reformasi. Kemampuan menafsirkan, menurut Nana Sudjana menunjukkan PPID sudah memiliki pemahaman yang sedang terhadap keterbukaan informasi publik. Beberapa istilah yang muncul dari pemahaman PPID terhadap keterbukaan informasi publik menurut PPID adalah sebagai berikut: 1). Keterbukaan informasi publik merupakan wujud partisipasi masyarakat dalam pemerintahan; 2). Keterbukaan informasi publik sebagai konsekuensi dari reformasi. Pemerintah dituntut terbuka kepada masyarakat, karena dalam penyelenggaraan pemerintahan menggunakan dana dari masyarakat; 3). Keterbukaan informasi publik merupakan bentuk diperlukan dalam rangka meningkatkan pengawasan masyarakat terhadap kegiatan pemerintah; 4). Keterbukaan informasi publik diperlukan dalam rangka mewujudkan good governance.

Penelitian ini juga menemukan bahwa PPID di Lingkungan Pemerintah Provinsi Banten memiliki pemahaman dalam kategori tinggi. Hal ini dibuktikan dengan PPID untuk melakukan ekstrapolasi terhadap keterbukaan informasi publik. Kemampuan ekstrapolasi adalah kemampun PPID melihat dibalik yang tertulis dalam undang-undang dan kemampuan meramalkan sesuatu. Dalam hal ini, PPID meramalkan bahwa akibat dari adanya keterbukaan informasi publik akan banyak permohonan informasi yang ditujukan kepada instansinya. Undang-undang memberikan kebebasan kepada masyarakat untuk, meminta informasi yang berkaitan dengan instansinya 
masing-masing. Sehubungan dengan hal tersebut, PPID harus mempersiapkan diri dalam memberikan pelayanan informasi tersebut. Berbagai upaya dilakukan PPID untuk memberikan layanan informasi, antara lain : 1). Menunjuk petugas pelayanan informasi; 2). Menindaklanjuti setiap permohonan informasi; 3). Menyediakan ruang pelayanan informasi; 4). Menyelenggarakan sosialisasi; 5). Membangun sistem pelayanan informasi berbasis website.

Langkah persiapan pelayanan informasi publik yang dilahirkan PPID sejalan dengan Pasal 7 Undang-undang Republik Indonesia Nomor 14 Tahun 2008 tentang Keterbukaan Informasi Publik. Pasal tersebut mewajibkan setiap badan publik dalam melaksanakan undang-undang tersebut, yaitu : 1). Badan Publik wajib menyediakan, memberikan dan/atau menerbitkan Informasi Publik yang beradadi bawah kewenangannya kepada pemohon Informasi Publik selain informasi yang dikecualikan sesuaidengan ketentuan; 2). Badan Publik wajib menyeiiiakan Informasi publik yang akurat, benar, dan tidak menyesatkan; 3). Untuk melaksanakan kewajiban sebagaimana di atas Badan Publik harus membangun dan mengembangkan sistem informasi dan dokumentasi untuk mengelola Informasi Publik seuara baik dan efisien sehingga dapat akses dengan mudah; 4). Badan Publik wajib membuat pertimbangan secara tertulis setiap kebijakan yang diambil untuk memenuhi hak setiap orang atas Informasi publik; 5). Pertimbangan sebagaimana dimaksud pada nomor 4 di atas, antara lain memuat pertimbangan politik, ekonomi,sosial, budaya danlatau pertahanan dan keemanan Negara; 6). Dalam rangka memenuhi kewajiban sebagaimana dimaksud diatas Badan Publik dapat memanfaatkan sarana dan/atau media elektronik dan non elektronik.

Dari hasil penelitian diperoleh gambaran bahwa tingkat kemampuan ekstrapolasi PPID terhadap keterbukaan informasi publik sangat dipengaruhi oleh jumlah perrnohonan yang diterima, pengalaman mengalami penyelesaian sengketa informasi melalui mediasi dan/atau sidang ajudikasi non litigasi di Komisi Informasi Provinsi Banten. Biro Humas dan Protokol Setda, Dinas Pendidikan dan Dinas Sumber Daya Air dan Permukiman menerima permohonan inforrnasi masing-masing sebanyak 66,45, dan 50 permohonan. Pengalaman melaksanakan penyelesaian sengketa inforrrasi melalui mediasi sebanyak 36 kali, 6 kali dan 3 kali. Sedangkan pengalaman penyelesaian sengketa infonnasi melalui sidang ajudikasi non litigasi masingmasing sebanyak 36 kali, 1 kali dan 3 kali.

Karakteristik di atas menunjukkan Biro Humas dan Protokol Setda Dinas Pendidikan dan Dinas Sumber Daya Air dan Permukiman memiliki pemahaman yang tinggi terhadap keterbukaan informasi publik yang dipengaruhi oleh tingkat permohonan informasi dan pengalaman menyelesaikan sengketa informasi. Akibat pemahaman yang tinggi itu, PPID telah menetapkan petugas pelayanan informasi, menindaklanjuti setiap permohonan informasi, menyediakan ruang pelayanan informasi, menyelenggarakan sosialisasi dan membangun sistem pelayanan informasi berbasis website. Hal ini dilaksanakan atas pelaksanaan kewajiban sesuai undang-undang setelah mereka sendiri 
memiliki pemahaman yang tinggi terhadap undanundang tersebut. Hal ini berbeda dengan Biro umum dan perlengkapan dan Dinas Kehutanan dan Perkebunan, yang masing-masing telah menerima permohonan informasi sebanyak 37 dan 22 permohonan, pengalaman mediasi dan sidang ajudikasi non litigasi sebanyak 3 kali. Tingkat pemahaman terhadap keterbukaan infomarsi publik bersifat sedang, karena melaksanakan UU KIP dengan menunjuk petugas layanan informasi, menindaklanjuti setiap penrrohonan informasi, dan menyelenggarakan sosialisasi UU KIP kepada pegawai di intemal Biro Umum dan Perlengkapan. Sementara Dinas Perindustrian dan Perdagangan masing-masing mendapatkan permohonan informasi sekitar 20 permohonan. Dinas ini, dalam melaksanakan UU KIP hanya melaksanakannya dengan menunjuk petugas layanan inforrnasi dan menindaklanjuti setiap permohonan informasi.

Menurut AIfred Schutz, tugas fenomenorogi adalah menghubungkan antara pengetahuan ilmiah dengan pengalaman seharihari, dan dari kegiatan dimana pengalaman dan pengetahuan itu berasal. Dengan kata lain mendasarkan tindakan sosial pada pengalaman, makna dan kesadaran (Kuswarno, 2009 : 17). Dalam hal ini, PPID melakukan tindakan dalam pelayanan inforrrasi. Tentu saja tindakan ini ada hubungannya dengan pengetahuan mereka terhadap keterbukaan informasi publik, sehingga dengan kesadarannya mereka melaksanakan tindakan untuk mempermudah pelayanan informasi dengan menyiapkan SDM, sarana dan prasarana dan menindaklanjuti setiap permohonan informasi. Kesadaran itu muncul setelah adanya pemahaman terhadap yang tinggi terhadap UU KIP. Pengalaman melayani permohonan informasi dengan junlah yang besar dan biasa-bisa saja menentukan tindakan mereka untuk memberikan pelayanan informasi.

Teori interaksionisme simbolik bisa juga dijadikan pedoman dalam membahas pemahaman PPID terhadap keterbukaan informasi publik, yang diwujudkan dalam tindakan dalam melaksanakan pelayanan informasi sesuai dengan undang-undang Republik Indonesia Nomor 14 Tahun 2008 tentang Keterbukaan Informasi Publik. Titik tolak interaksi simbolik berasumsi bahwa realitas sosial sebagai proses dan bukan sesuatu yang bersifat statis. Menurut George Herbert Mead, cara manusia mengartikan dunia dan dirinya sendiri berkaitan erat dengan masyarakatnya. Mead melihat pikiran (mind) dan dirinya (self) menjadi bagian dari perilaku manusia yaitu bagian interaksinya dengan orang lain. Mead menambahkan bahwa sebelum seseorang bertindak, ia membayangkan dirinya dalam posisi orang lain dengan harapan-harapan orang lain dan mencoba memahami apa yang diharapkan orang itu (Mulyana, 2007).

Sementara itu Herbert Blumer terdapat tiga prinsip utama menurut Teori lnteraksionisme Simbolik, yaitu : 1). Manusia bertindak melalui hal-hal pada makna yang ada di dalamnya; 2). Makna-makna tersebut muncul dari interaksi sosial; 3). Tindakan sosial merupakan hasil dari tindakan-tindakan individu.

Dalam hal ini, PPID memahami keterbukaan informasi publik dengan melakukan tindakan-tindakan, seperti menunjuk petugas pelayanan informasi publik menindaklanjuti setiap 
permohonan informasi, menyediakan sarana dan prasarana pelayanan informasi publik, membuat sistem pelayanan informasi berbasis website, dan menyelenggarakan sosialisasi keterbukaan informasi di lingkungannya. Tindakan PPID tersebut berdasarkan pada pemaknaan yang dimilikinya dan makna-makna tersebut muncul setelah PPID melakukan interaksi dengan lingkungannya, dalam hal ini pemohon informasi.

\section{Makna Pemohon Informasi dari PPID di}

\section{Lingkungan pemerintah Provinsi Banten}

Pemohon informasi adalah dua pihak yang saling berinteraksi dalam proses pelayanan informasi. Sikap PPID dalam memberikan pelayanan informasi sangat dipengaruhi oleh pemaknaan yang dimiliki PPID terhadap pemohon informasi. Sehubugan dengan hal tersebut, penelitian ini bertujuan bagaimana PPID memberikan makna terhadap pemohon informasi. Pemaknaan positif PPID terhadap pemohon informasi menyebabkan PPID bersikap terbuka dalam memberikan layanan informasi. Dalam pengertian, PPID sebagai pihak yang menguasai informasi akan mudah memberikan informasi tersebut kepada pemohon. Dan sebalik ya apabila PPID memiliki pemahanan yang negatif terhadap pemohon informasi cenderung bersikap tertutup.

Dilihat dari fenomenologi, PPID merupakan aktor yang melakukaan tindakan sosial (melakukan pemaknaan terhadap pemohon informasi) yang saling terkait dengan tindakan aktor-aktor lain disekitamya. Ketika para informan melakukan pemahaman terhadap sesuatu, mereka memaknai sesuatu secara berbeda-beda. Proses seseorang memaknai sesuatu tidak terlepas dari latar belakang, pengetahuan yang dimilikinya serta lingkungan yang mempengaruhi cara seseorang memandang sesuatu.

Menurut Schutz dalam menelaah tindakan seseorang yang umum dalam dunia kehidupan tidak dapat lepas dari pengaruh situasi biografinya. Makna yang terbangun dari setiap interaksi yang terbangun tidak lepas dari latar belakang biografis. Proses pemaknaan di atas ini membentuk sistem relevansi yang menjalankan proses interaksi dengan lingkungan. Dengan kata lain, pembentukan sistem relevansi dalam proses interaksi sosial ini dapat dijadikan elemen pembentuk tujuan dalam setiap tindakan sosial yang dilakukan oleh individu.

Dalam hal PPID memaknai pemohon informasi, makna yang terbangun tidak terlepas dari setiap interaksi dan kondisi disekitarnya. Terdapat beberapa makna yang disampaikan informan dalam memandang pemohon informasi, yaitu melihat pemohon sebagai warga Negara yang memiliki hak untuk meminta informasi karena dilindungi undang-undang, pemohon informasi menjadi seseorang yang melakukan investigasi terhadap kegiatan yang ada di SKPD Pemprov Banten, pemohon informasi yang hanya sekedar meminta informasi tanpa tujuan yang jelas, dan pemohon informasi yang memiliki tujuan bertemu dengan pejabat.

Pemaknaan tersebut tidak terlepas dari pengalaman PPID selama menjadi pelayanan informasi yang dipengaruhi oleh kondisi geografis seseorang, misalnya pengetahuan, latar belakang pendidikan atau jabatan PPID, dan intensitas pelayanan informasi. Pengetahuan dan 
pemahaman PPID terhadap kebijakan,

keterbukaan informasi publik memandang pemohon sebagai orang yang sedang menggunakan haknya yaitu hak sebagai warga negara untuk meminta informasi. Norma dasar penggunaan hak tersebut adalah Pasal 28F Undang-undang Dasar 1945 hasil amandemen kedua, yang menyebutkan bahwa setiap orang berhak untuk berkomunikasi dan memperoleh informasi untuk mengembangkan pribadi dan lingkungan sosialnya, serta berhak untuk mencari, memperoleh, memiliki, menyimpan, mengolah, dan menyampaikan informasi dengan menggunakan segala jenis saluran yang tersedia (Arifin, Anwar, 2010 : 169).

Hasil penelitian menemukan, semua informan penelitian ini, dari sisi idealisme menyatakan, pemohon informasi adalah perorangan atau lembaga yang menggunakan haknya sebagai warga negara, yaitu hak ingin tahu. Hak atas informasi merupakan hak dasar yang menjadi sokoguru pemerintahan yang transparan dan partisipatoris, merupakan jalan lempang bagi tersedianya jaminan pemenuhan hak-hak fundamental dan kebebasan lainnya. Hak atas informasi hanya dapat dibatasi oleh dan berdasarkan UU. Dan, pemerintah sebagai badan publik berkewajiban memenuhi hak warga Negara terhadap informasi. Pemenuhan hak atas kebebasan memperoleh informasi publik merupakan salah satu indikator dianutnya konsepsi negara hukum sekaligus demokrasi yang bercirikan pengakuan atas hak asasi. Menurut Jimly Asshidiqie, dalam konsep negara hukum yang demokratis (democratische rechtsstaat) atau negara demokrasi berdasar atas hukum, salah satu ciri pokoknya adanya pengakuan dan penghormatan terhadap hak asasi manusia.

Sementara itu dalam individu yang sama muncul pemikiran yang berbeda terhadap pemohon informasi. Pemaknaan terhadap pemohon bersifat positif dan negatif. Makna positif adalah PPID menyebut PPID sebagai pihak yang berpartisipasi dalam kegiatan pemerintahaa rtan sebagai pihak yang menggunakan haknya untuk tahu tentang kegiatan pemerintahan. Sedangkan makna negatif dari PPID terhadap pemohon informasi adalah pemohon informasi sebagai pihak yang asal-asalan, berlebihan dan berlebihan dalam mengajukan permohonan.

Faktor-faktor yang mempengaruhi pemaknaan tersebut adalah tingkat keseringan mengalami proses sengketa informasi di Komisi Informasi, sifat permohonan yang diajukan pemohon dan cara pemohon mengajukan perrnohonan. PPID yang lebih sering mengalami proses sengketa informasi, sifat permohonan yang dilayangkan pemohon bersifat positif cenderung menilai positif pemohon informasi, sedangkan PPID yang hanya satu kali mengalami sengketa cenderung, mendapatkan permohonan informasi yang cenderung menyudutkan dan berlebihan, serta tidak memiliki aktivitas diluar kantor cenderung menilai negatif pemohon informasi.

Bersifat positif artinya, PPID memaknai pemohon informasi sebagai pihak yang mengajukan permohonan informasi karena memang benar-benar membutuhkan informasi yang dimintakan. Sehingga PPID melayani pemohon informasi tersebut sesuai dengan peraturan perundangan yang berlaku. Bersifat negatif, PPID memaknai pemohon informasi yang 
memiliki tujuan bukan untuk mendapatkan informasi. Tetapi, memohon informasi dengan alasan undang-undang tetapi memiliki tujuan lain. Seperti diungkapkan PPID pada Dinas Perindustrian dan Perdagangan, misalnya. Pemohon informasi meminta informasi pengadaan barang dan jasa, misalnya, pada ujung-ujungnya pemohon informasi tersebut memintah "jatah" untuk diberikan pekerjaan penhadaan barang dan jasa tersebut. Demikian juga diungkapkan oleh PPID pada Dinas Pendidikan Provinsi Banten. Pemohon informasi hanya mengajukan permohonan informasi sekedar untuk bertemu dengan pejabat, dan selanjutnya membuat dealdeal tertentu dengan pejabat yang bersangkutan. Dalam hal ini, tujuan keterbukaan informasi sangat konttraproduktif dengan tujuan awal untuk menciptakan clean government dan good governance.

Pemaknan positif dan negatif PPID terhadap pemohon informasi sangat dipengaruhi oleh kuantitas permohonan informasi dan penyelesaian sengketa informasi. Biro Humas dan protokol serta Biro umum dan perlengkapan masing masing telah mengalami sengketa informasi sebanyak 36 kali dan 4 kali. Kedua unit kerja pada Sekretariat Daerah Provinsi Banten ini memaknai positif. Memaknai positif, Biro Humas dan Protokol menyebut pemohon informasi sebagai pihak yang berpartisipasi dalam kegiatan pemerintahan. Sedangkan, PPID Biro umum dan Protokol menyebutnya sebagai pihak yang memiliki hak untuk mengetahui proses perjalanan pemerintahan. Meskipun, dibalik penilaian positif, keduanya menemukan keganjilan dari pemohon informasi. Biro Humas dan Protokol menemukan pemohon yang tidak memiliki tujuan yang jelas dalam mengajukan permohonan. Artinya setelah diajak berdiskusi beberapa pemohon informasi tidak membutuhkan informasi yang diminta tetapi sekedar berniat bertemu dengan kepala Biro Humas dan protokol. Sedangkan, PPID pembantu pata Biro umum dan perlengkapan mensinyalir adanya motif lain dibalik pennohonan informasi. Indikasi tersebut antara lain, ketika pemohon informasi mendapatkan data tentang pagu anggaran sebuah kegiatan, maka pemohon informasi langsung menyebut adanya indikasi penyelewengan, tanpa melakukan kajian atau penelitian terhadap pagu anggaran kegiatan tersebut.

PPID pada Dinas Perindustian dan perdagangan baru satu kali mengalami proses sengketa informasi melalui mediasi dan sidang ajudikasi non litigasi di Komisi Informasi. Selain itu pihak Dinas Perindustian dan perdagangan sering menerima permohonan informasi yang tidak memiliki tujuan jelas tentang penggunaan informasi. Hasil penelitian menunjukkan, PPID pada Dinas Perindustrian dan Perdagangan menilai pemohon informasi sebagai pihak yang, mengajukan perrnohonan asal-asalan. PPID Dinas perindustian dan perdagangan memaknai pemohon informasi sebagai pihak yang bertujuan untuk menaikkan posisi tawar untuk menekan pihak dinas. PPID pada Dinas Pendidikan dan PPID pada Dinas Sumber daya Air dan Permukiman telah mengalami beberapa kali proses sengketa informasi melalui mediasi dan satu kali sidang ajudikasi non litigasi di Komisi Informasi. Namun, PPID pada Dinas Pendidikan provinsi Banten, Ade Kosasih, S.Pd., M.Pd, kerap 
menerima permohonan informasi yang berlebihan seperti meminta data dan informasi seluruh kegiatan pada Dinas pendidikan provinsi Banten selama satu tahun. Menurut pengakuannya, permohonan informasi tersebut menyulitkan dirinya untuk menyediakan seluruh permintaan tersebut. Maklum, kegiatan pada Dinas Pendidikan sangat banyak dan mengunakan anggaran yang sangat besar, mencapai ratusan milyar.

Sehubungan dengan hal tersebut, PPID pada Dinas Pendidikan menilai pemohon informasi berlebihan. Dan, dia menuduh pemohon informasi menggunakan status pemohon untuk bisa bertemu dengan PPTK. Hal ini muncul karena hasil interaksi antara dirinya dengan pemohon informasi yang menyatakan bahwa kepentingan sebenarnya dari pemohon informasi bukan untuk mendapatkan informasi tetapi untuk bertemu dengan pejabat. Dimana, hasil pertemuan tersebut tidak bisa diketahui lagi oleh dirinya.

Sementara PPID Pembantu pada Dinas Sumber Daya Air dan Permukiman, memaknai pemohon informasi sebagai investigator. Hal ini melihat karena PPID Pembantu Dinas SDA dan perrnukiman kerap mendapatkan surat permohonan informasi yang sifat minta klasifikasi atas investigasi yang telah dilakukan oleh pemohon informasi. Kalimat-kalimat investigasi itulah yang membuat PPID Pembantu Dinas SDA dan permukiman menilai negatif sebagai pelaku investigasi terhadap pemohon informasi. Hal ini disimpulkan setelah dikalkulasi bahwa antara pemohon informasi sebagai pelaku investigasi dengan pemohon informasi yang benar-benar membutuhkan informasi dengan perbandingan 80 banding 20 persen.

PPID pada Dinas Kehutanan dan perkebunan, Deni Andriani, S.Sos.,M.si, baru satu kali mengalami proses sengketa informasi baik melalui mediasi maupun sidang ajudikasi non litigasi. Tetapi, sifat permohonan informasi yang diterima rata-rata bersifat positif. Informasi yang diminta rata-rata data dan informasi kegiatan unggulan Dinas Kehutanan dan Perkebunan. Sebagai contoh, permintaan data kegiatan pembuatan Taman Hutan Raya Provinsi Banten. Informasi yang diminta menyangkut nominal anggaran, tujuan pelaksanaan kegiatan, dan sejauhmana kegiatan dilakukan. Dalam penelitian ini, PPID Dinas Kehutanan dan Perkebunan memaknai positif pemohon informasi, yaitu sebagai pihak yang berhak tahu atas inforrnasi publik yang ada di Lingkungan Dinas Kehutanan dan Perkebunan.

Pemaknaan seseorang obyek juga bisa dilihat dari sudut teori interaksioneine simbolik. Menurut fenomenologi, proses pemaknaan seseorang terhadap suatu obyek melihat kepada pemahaman terhadap pengalaman subyektif seseorang atas suatu peristiwa, maka interaksionisme simbolik fokus kepada penafsiran terhadap pemaknaan subyektif yang muncul dari hasil interaksi dengan orang lain atau lingkungannya dalam hal ini interaksi antara PPID dengan pemohon informasi.

Dalam hal ini terdapat interaksi dengan pengoperan lambang-lambang antara PPID dengan pemohon informasi. Dari pengoperan lambang-lambang tersebut, kemudian muncul pemaknaan PPID terhadap pemohon informasi. 
Proses pengoperan lambing-rambang ini yang membedakan pemaknaan PPID terhadap pemohon informasi. Teori Interaksionisme Simbolik menyatakan, individu membentuk makna melalui komunikasi karena makna tidak bersifat intrinsik terhadap apapun. Dibutuhkan kontruksi interpretative diantara orang-orang untuk menciptakan makna. Bahkan, tujuan dari interaksi adalah untuk menciptakan makna yang sama. Hal ini penting karena tanpa makna yang srma dalam berkomunikasi akan menjadi sulit atau bahkan tidak mungkin.

Makna pemohon informasi dari PPID merupakan hasil interaksi dan pengoperan lambang-lambang antara PPID dengan pemohon informasi. Artinya, PPID memberikan makna terhadap pemohon informasi setelah melalui serangkaian pengalaman dalam melaksanakan pelayanan informasi. Berbagai penemuan tersebut sejalan dengan inti Teori Interaksionisme Simbolik. Ide dasar teori interaksionisme simbolik adalah bahwa tindakan dan interaksi manusia hanya dapat dipaharni melalui pertukaran simbol atau komunikasi yang sarat makna. Interaksionisme simbolik berakar dari dua kata yang bermakna berbeda yaitu interaksi dan simbol. Simbolik mengandung pengertian pada makna yang terdapat pada situasi sosial tertentu di mana pelaku berada di dalamnya, sedangkan interaksionis mengandung arti makib tersebut dibentuk oleh interaksi di antara pelaku.

Menurut George Herbert Mead, cara manusia mengartikan dunia dan dirinya sendiri berkaitan erat dengan masyarakatnya. Mead melihat pikiran (mind) dan dirinya (self) menjadi bagian dari perilaku manusia yaitu bagian dengan orang lain. Mead menambahkan bahwa sebelum seseorang bertindak ia membayangkan dirinya dalam posisi orang lain dengan harapan-harapan orang lain dan mencoba memahami apa yang diharapkan orang itu (Mulyana 2007). Gambaran pembahasan di atas peneliti mengkontruksikan bahwa terdapat dua sisi pemaknaan PPID Pemerintah Provinsi Banten terhadap pemohon informasi. Sisi pertama, memandang pemohon informasi positif. Mereka memaknai informasi sebagai warga negara yang sedang menggunakan haknya. Selain itu pemohon informasi menunjukkan peran serta (partisipasi) masyarakat dalam proses pemerintahan. Pemaknaan tersebut muncul sebagai sisi idealisme PPID atas pengetahuan dan pemahaman mereka terhadap Undang-undang KIP. Sementara pada bagian lain, PPID memaknai pemohon berdasarkan pengalarnan sadar mereka pada saat berinteraksi dengan pemohon informasi. Ketika itu, terjadi pengoperan lambang-lambang antara kedua belah pihak. PPID yang menerima permohonan informasi dengan mayoritas dari LSM yang melayangkan permohonan informasi bersifat negatif seperti tidak memiliki tujuan penggunaan yang jelas, meminta informasi secara berlebihan dan berita melakukan investigasi terhadap kegiatan yang sedang dijalankan oleh pemerintah. Sehingga, PPID cenderung memaknai negatif terhadap pemohon informasi. Bahkan cenderung memaknai pemohon informasi memiliki tujuan lain, yakni bertemu PPTK, tidak sekedar memohon informasi. Makna lainnya yang muncul bahwa pemohon informasi memiliki motif tertentu investigator, dan asal memohon informasi karena tidak memiliki tujuan yang jelas serta tidak 
relevan dengan aktivitas kesehariannya. Sedangkan, PPID yang mayoritas menerima permohonan informasi yang sifatnya positif cenderung memaknai pemohon sebagai pihak yang menggunakan haknya untuk tahu kegiatan pemerintahan. Sehingga mereka cenderung lebih terbuka dibanding dengan PPID yang banyak menerima permohonan dari pemohon yang sifatnya negatif.

\section{Daftar Pustaka}

Amsyah, Zulkifli, Drs. MLS. 2003. Manajemen Sistem Informasi. PT. Gramedia Pustaka Utama. Jakarta.

Creswell, John W. 1998. Qualitative Inquiry and Research Design; Choosing Among Five Traditions. The United states of America :sagePublikations, inc.

Fatah, Eef Saefullah. 2000. Pengkhianatan Demokrasi Ala Orde Baru. Masalah dan Masa Depan Demokrasi Terpimpin Konstitusional. PT Remaja Rosda Karya. Bandung.

George R. Terry, Ph.D., office Management and control, Fourth Edition, Richard D. kwin Inc., Homewood, Ilinois, 1962, Halaman 21.

Kartono, Kartini, Dali Gulo. 1997. Kamus Psikologi. Pustaka Setia Bandung.

Kuswarno, E. 2009 Metode Penelitian Fenomenologi Konsepsi Pedoman dan Contoh Penelitiannya, Widya Padjadjaran, Bandung

Lindlof Thomas R. 1995. Quolitative Communication Research Methods. California : Sage Publikations Inc. USA

Moloeng, Lexy J- 2003. Metodologi Penelitian Kualitatif. Bandung : Remaja Rosdakarya.
Nasution, S. 2003. Metode Penelitian Naturalistik Kuatitatif. Bandung: Tarsito

Ratna K. Metodelogi penelitian Kajian Budaya dan Sosial Humaniora pada Umumnya, Pustaka pelajar, Yogyakarta 194

Schutz A. 1967. The Phenomenologi of The Social World. Evanston, IL : North Western Unviersity Press.

Sudjana Nana. 2006. Penilaian Hasil Proses Belajar Mengajar. Rosda Karya. Bandung.

Suryabarata, Suryadi. I991. Psikologi Pendidikan. Rajawali. Jakarta.

Undang-undang dan Peraturan Lainnya:
Peraturan Gubemur Banten Nomor 16 tahun 2011tentang Pedoman
PengelolaanDokumentasi di
Lingkungandan Pelayanan Informasi Publik danPemerintah Provinsi Banten.

Peraturan Menteri dalam Negeri Republik Indonesia Nomor 13 Tahun 2010tentang Pedoman Pengelolaan Pelayanan Informasi Dan DokumentasiDi Lingkungan Kementerian Dalam Negeri Dan Pemerintahan Daerah

Peraturan Pemerintah Republik Indonesia Nomor 61 tahun 2010 tentangPelaksanaan Undang-undang Republik Indonesia Nomor 14'Tahun2012 tentarg Keterbukaan Informasi Publik

Peraturan Komisi Informasi Republik Indonesia Nomor 1 Tahun 2010 tentangStandar Layanan Informasi Publik.

Undang-undang Republik Indonesia Nomor 14 Tahun 2012 tentang Keterbukaan lnformasi Publik

\section{Lain-Lain}

Data Kegiatan Biro Humas dan Protokol Sekretariat Daerah Provinsi Bantentahun 2010,2011.

Data Pelayanan informasi pada PPID di Lingkungan Pemerintah ProvinsiBanten, Juli2012. 
Data pada Komisi Informasi Provinsi Banten per Juli 2012.

Harian Radar Banten edisi 21 Februari 12 hal 1. Sekda Sosialisosikan UU KIP.

Harian Radar Banten Edisi 20 Maret 2012, hal. 13, Permintaan Informasi Berujung Pemerasan.

http://komisiinformasi.bantenprov.go.idlharusmampu-dorong-badan-publik-beriinformasi. Diakses tanggal 13 Agustus 2012 pukul 21.36 WIB.

http://www.radarbanten.comlmod.php?mod:publis her\&op:viewarlicle.artid:59270Pelayoaan Informasi Pemprov Banten mengecewakan. Diakses tanggal 2 Agustus 2012 pukul I I:31 AM.

Ismanto, 2011. Banten Menuju Era Keterbukaan Informasi : Best Practice Pembentukan Komisi Informasi Provinsi dalam Jurnal Proceeding Simposium Nasional Otonomi Daerah 201 I LAB-ANE FISIP Untirta.

Keat, Joan, Teori InteraksionismeSimbolik. http://id.shvoong.com/social-sciences/so ciology /22262 81 -teori-interaksionismesimbohk/ -\#txz-223 -XYwU00, Diaksestzrrggal 13 Agustus 2012 pukul 14.58 WIB. 196

Laporan Kegiatan Sosialisasi Keterbukaan Informasi Publik kepada SKPD di Lingkungan Pemerintah Provinsi Banten pada Biro Humas dan Protokol Sekretariat Daerah Provinsi Banten tahun 2012.

Supriatna Kusma. 2012. Kebebasan Pers dan Demokrasi, dalam Harian Umum Banten Raya Post Edisi 8 Februari 2012,Hal. 4.

Supriatna Kusma. 2012. Pemprov Patuhi KIP, dalam Harian umum KabarBanten Edisi 25 Februari 2012, Hal. 8. 